\title{
OB TEJ IN PRIHODNJIH ŠTEVILKAH BILTENA SLOVENSKE VOJSKE
}

\author{
IN THIS AND ALL THE FOLLOWING ISSUES \\ OF THE SLOVENIAN ARMED FORCES BULLETIN
}

Po osmih letih izhajanja je pred nami nova številka Biltena Slovenske vojske $\mathrm{z}$ nekoliko spremenjeno zunanjo in novo notranjo podobo. To naj bi po svoje vplivalo tako na vsebino kot na kakovost prispevkov. Spremembe so bile porojene med snovalci novega Navodila za pripravo in izdajanje periodičnih publikacij Slovenske vojske, ena izmed njih je tudi Bilten. Začelo se je pred devetimi leti, na pobudo takratnega načelnika Generalštaba. Že na začetku izhajanja je bil Bilten postavljen na dobre temelje in je svoje poslanstvo do danes dobro opravil, čeprav je sčasoma presegel okvir dosedanjega navodila. Njegovo izhajanje je slonelo na prostovoljnem delu nekaj zanesenjakov, ki so poleg rednega dela, ki ga ni bilo malo, skrbeli za njegovo izhajanje. Njegova pot ni bila vedno lahka, saj je doživljal večje ali manjše zastoje in težave. Da pa bi mu bilo v prihodnosti lažje, smo v analizo dosedanjega dela ter snovanje in oblikovanje novega navodila vložili veliko truda in energije, kar pomeni, da smo se dela lotili resno in premišljeno.

Tako so periodične publikacije Slovenske vojske, in tudi Bilten, postavljene na nove temelje, pred nove izzive, $\mathrm{z}$ namenom, da bi bralcem ponudile višjo raven objavljenih prispevkov. Ta želja je pri odgovornih članih uredniških odborov Biltena tlela že nekaj let. Snovalci so si pri oblikovanju novega navodila zastavili visoke cilje, z vizijo in ambicijo, da bi bila kakovost in stremljenje k odličnosti vsem avtorjem vodilo in cilj pri pisanju prispevkov. Prispevala naj bi tudi k njihovemu usposabljanju za oblikovanje vsebin, ki jih pripravljajo za objavo v publikacijah Slovenske vojske, Ministrstva za obrambo in drugih ustanov, predvsem pa v Biltenu. Poleg tega smo z novim navodilom razširili krog piscev. V Biltenu lahko zdaj objavljajo tudi zunanji avtorji. Omogočena pa je tudi mednarodna izmenjava prispevkov s publikacijami podobnih vsebin. 
Bilten Slovenske vojske ostaja periodična vojaškostrokovna in informativna publikacija, namenjena izobraževanju in obveščanju javnosti o dosežkih ter izkušnjah na področju vojaških, vojaško-tehničnih in drugih ved, vendar na višji ravni.

Teme, ki jih avtorji izbirajo, so z vojaškega področja, od doktrinarnih in strateških zamisli, vedno aktualnih operatike ali taktike uporabe enot Slovenske vojske, do uporabe enot na mirovnih misijah in v operacijah pod vodstvom Nata, EU ali OZN. Dobrodošle bodo tudi teme o usposabljanjih, rezultatih streljanja in druge, ki v Slovensko vojsko prinašajo novo znanje in nove veščine. Pisci si lahko izberejo teme o organizaciji in organiziranosti Slovenske vojske, kakovosti na splošno ali odličnosti in dobrih praksah, ki so za vojsko zelo pomembne.

Tudi štipendisti ministrstva lahko s svojim znanjem prispevajo $\mathrm{k}$ nadaljnjemu razvoju Slovenske vojske. Za objavo lahko priredijo svoje vojaškostrokovne seminarske in zaključne oziroma diplomske naloge ter druga dela iz dodiplomskega študija. To velja tudi za študente podiplomskega študija oziroma njihova seminarska in podiplomska dela.

Z novim navodilom so lahko prispevki napisani v slovenskem jeziku, z naslovom, ključnimi besedami in povzetkom $\mathrm{v}$ angleškem jeziku, ali $\mathrm{v}$ angleškem jeziku, $\mathrm{z}$ naslovom, ključnimi besedami in povzetkom v slovenskem jeziku. V angleški jezik sta prevedena tudi kazalo in kolofon. Prispevki so opremljeni z oznako UDK, vrste člankov pa so določene s tipologijo COBISS. Tako smo dosegli, da bodo avtorji z objavo prispevkov dosegli točke za habilitacijo.

Vse to nam omogoča, da lahko glavni in odgovorni urednik načrtujeta tudi mednarodno sodelovanje in izmenjavo prispevkov.

O objavi prispevka odloča uredniški odbor pred oddajo v recenzijo. Vedeti pa je treba, da prispevkov z žaljivo ali neprimerno vsebino ne bo sprejemal. Opozarjamo tudi, da so objavljeni prispevki avtorski in ne predstavljajo stališč Slovenske vojske ali izdajateljev.

Da bi dvignili kakovost objavljenih prispevkov, smo se pri oblikovanju novega navodila odločili, da bo uredniški odbor sestavljen iz članov z akademskimi in strokovnimi naslovi, dopolnjevali pa ga bodo zunanji člani.

Za objavo v Biltenu morajo avtorji upoštevati navodilo za pisanje prispevkov, ki je v vsaki številki objavljeno na notranji strani zadnje platnice in na spletni strani. V navodilu so prikazani tudi klasifikacija zvrsti prispevkov in posamezni standardi ISO, ki jih je treba pri oblikovanju upoštevati.

Pripadnike Slovenske vojske vabimo, naj začnejo pripravljati prispevke, naj svoje sodelovanje v Biltenu sprejmejo kot izziv, saj bodo tako dokazali svojo strokovnost in željo po širjenju splošnega in posebnega znanja. Prepričani smo, da mora 
posameznik, če hoče uspeti, imeti resnično voljo, da svoje sposobnosti čim bolje uporabi za opravljanje pravega in ustvarjalnega dela. Tako lahko izrazi svojo celovito osebnost ter uresniči svoje želje in hrepenenja, kar bo omogočil tudi Bilten.

Pri oblikovanju svojih prispevkov bodo pripadniki Slovenske vojske in drugi spoznali, da je težek samo začetek. Že Sun $\mathrm{Cu}$, ki velja za največjega stratega vseh časov, je pred skoraj 3000 leti zapisal, da se še tako težka pot začne s prvim korakom. 